\title{
Hráze historických rybníků z pohledu tvaru a stability
}

\section{KATEŘINA ČERNOCHOVÁ, VÁCLAV DAVID}

Klíčová slova: rybník - tvar hráze - stabilita hráze - Kostelecko

\section{SOUHRN}

Článek představuje výsledky hodnocení tvaru hrází rybníků v oblasti Kostelecka a Kouřimska ve Středočeském kraji. Tvar hrází byl posuzován na základě podrobného digitálního modelu terénu založeného na datech Digitálního modelu reliéfu 5. generace. Hodnocení bylo provedeno pro celkem 30 hrází v zájmovém území. Z výsledků provedených analýz vyplývá, že řada hrází má hráze se svahy strmějšími, než doporučuje pro homogenní hráze v současnosti platná norma ČSN 75 2410. V některých případech jsou oproti normě strmější oba svahy, návodní i vzdušní, v některých prípadech pouze jeden z nich. Na vybrané hrázi Podbečvárského rybníka bylo následně provedeno posouzení stability s využitím modelu SSAP. Výsledky hodnocení stability ukazují, že daná hráz nedosahuje požadovaného stupně stability daného normou ČSN 75 2410, byt̉ to samozřejmě neznamená, že by byla akutně ohrožena. Prezentovaný postup představuje možnost, jak přistupovat k hodnocení bezpečnosti hrází malých vodních nádrží v rozsáhlejších územích za účelem identifikace potenciálního nebezpečí souvisejícího se sníženou stabilitou těchto zemních těles.

\section{ÚVOD}

Historie rybníků na území současné České republiky je více než tisíciletá. Jako první doklad o existenci stavby, kterou je možno označovat za rybník, je existence osady Rybníček, která existovala již v roce 993 v prostoru mezi dnešními ulicemi Ječná a Žitná v Praze na Novém Městě [1]. Zde byla archeologickým výzkumem v roce 1998 odhalena malá nádrž o rozměrech 6 × 12 m, Ize však předpokládat, že tato nádrž spíše využívala k zadržení vody konfigurace terénu a jeho menších úprav, než aby měla klasickou hráz a objekty, jak je známe dnes. Za první písemnou zmínku o existenci rybníka je pak považován dodatek Mnicha sázavského ke Kosmově kronice o založení Sázavského kláštera, v němž je uvedeno, že kníže Břetislav „z vlastní štědrosti odevzdal (klášteru, pozn. aut.) okolní zemi až k lesu Strnovníku, též ves Skramníky, jeden rybník a slup k lovení ryb..." [2]. Obecně jsou většinou autorů počátky budování rybníků datovány do období 9. až 12. století [3, 4]. Doklady z tohoto období jsou velmi omezené, Ize však předpokládat, že zakládané rybníky byly zpravidla ojedinělé a měly poměrně nízké hráze. Masivnější budování rybníků spadá do období vlády Karla IV., zejména pak ovšem do období tzv. zlatého věku rybnikářství, který je obvykle vymezován jako perioda mezi husitskými válkami a válkou třicetiletou, konkrétněji jako poslední čtvrtina 15. století a celé 16. století [5, 6].

Stejně jako ostatní obory i rybnikářské stavitelství prošlo po dobu své existence vývojem, který se projevil v řadě aspektů. Jedním z těch hlavních je tvar hráze, který byl historicky jiný než v současnosti. Rozdíl spočívá především ve sklonech svahů historických hrází, které byly obecně prudší než ty, které jsou doporučovány

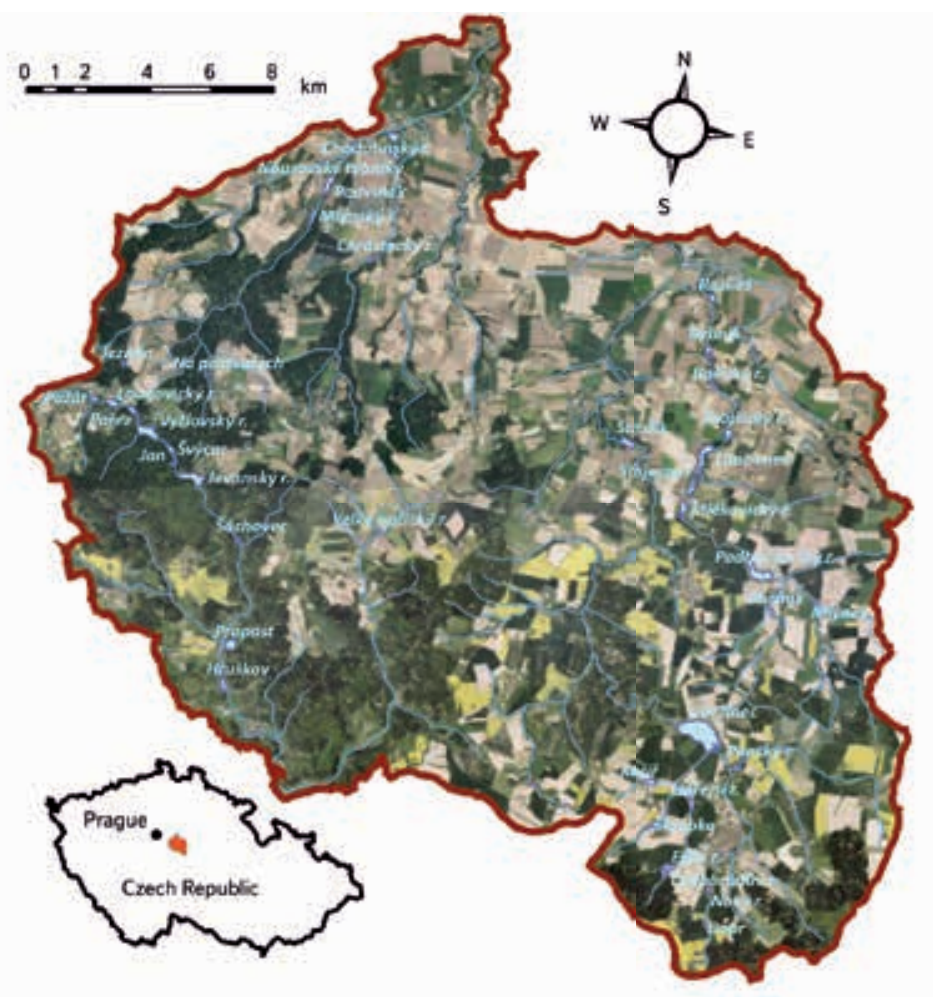

Obr. 1. Mapa zájmové oblasti s vyznačením polohy rybníků posuzovaných s ohledem na tvar jejich hráze

Fig. 1. Map of the investigated area with the location of fishponds evaluated from the point of view of the shape of the dam body

současnými normativními předpisy. Z nejstaršího technologického předpisu zahrnujícího i technologii výstavby hráze sepsaného olomouckým biskupem Janem Skálou z Doubravy (Jan Dubravius) pod názvem De Piscinis (O rybnících) [3] vyplývá, že doporučený sklon návodního i vzdušního líce činí 1 : 1, zatímco současná norma ČSN 752410 Malé vodní nádrže [7] doporučuje u zemin vhodných pro budování homogenních hrází sklony minimálně $1: 2$ na vzdušním líci a 1:3. Mimo technologický aspekt Ize za významné pokládat i to, že rybníky byly historicky budovány $\vee$ kaskádách, což umožňovalo lepší hospodaření s vodou v nich. $V$ té době to bylo samozřejmě mnohem snadnější vzhledem k majetkovým vztahům k půdě, kdy nebyly vlastnické poměry tak roztřrištěné jako v současnosti a zejména šlechta měla v držení dostatek půdy pro budování takovýchto systémů. Kaskády rybníků ovšem skrývají jedno podstatné riziko, a tím je vznik dominového efektu při protržení hráze jednoho z výše položených rybníků [8]. 
Tabulka 1. Výsledné hodnoty sklonů pro hráze hodnocených rybníků

Table 1. Resulting slope values for dams of assessed fishponds

Sklon vzdušního líce (\%)

Sklon návodního líce (\%)

\begin{tabular}{|c|c|c|c|c|c|c|c|c|}
\hline Název rybníka & Průmèr & Min. & Max. & Sm. odch. & Průmèr & Min. & Max. & Sm. odch. \\
\hline Nový r. & 46,6 & 31,7 & 67,5 & 7,7 & 29,2 & 17,5 & 40,5 & 4,4 \\
\hline Panský r. & 42,2 & 32,1 & 49,9 & 3,4 & 20,8 & 13,5 & 26,0 & 2,5 \\
\hline Škrobka & 38,6 & 25,2 & 49,6 & 5,9 & 13,8 & 4,8 & 22,5 & 4,2 \\
\hline Dolní Ostašov & 38,0 & 23,3 & 49,8 & 7,4 & 9,9 & 4,6 & 13,6 & 2,3 \\
\hline Hořejší r. & 28,5 & 18,2 & 36,8 & 4,2 & 20,3 & 7,6 & 29,4 & 5,2 \\
\hline Kačír & 38,3 & 24,6 & 57,8 & 7,7 & 21,2 & 13,6 & 31,9 & 4,7 \\
\hline Vavřinec & 51,3 & 22,0 & 77,9 & 12,6 & 36,5 & 25,5 & 46,9 & 4,2 \\
\hline Strašík & 52,9 & 31,0 & 65,0 & 7,1 & 34,2 & 29,6 & 38,0 & 2,2 \\
\hline Frčina & 45,5 & 26,4 & 55,0 & 6,7 & 30,1 & 24,2 & 36,5 & 2,8 \\
\hline Mlýnek & 51,9 & 26,0 & 68,9 & 9,9 & 26,2 & 14,1 & 44,8 & 8,3 \\
\hline Bosňák & 56,9 & 48,6 & 62,4 & 3,4 & 9,5 & 4,6 & 16,4 & 3,0 \\
\hline Stojespal & 34,5 & 17,9 & 46,2 & 6,5 & 8,8 & 2,3 & 12,3 & 2,2 \\
\hline Podbečvárský r. & 59,8 & 48,8 & 66,5 & 3,9 & 32,2 & 25,3 & 38,0 & 2,5 \\
\hline Mlékovický r. & 58,6 & 33,0 & 72,6 & 8,6 & 27,5 & 17,3 & 37,7 & 4,7 \\
\hline Svojšický r. & 63,8 & 33,0 & 81,7 & 12,1 & 29,1 & 16,4 & 46,4 & 7,8 \\
\hline Rozkoš & 51,4 & 28,4 & 63,1 & 8,5 & 21,1 & 13,0 & 24,7 & 2,7 \\
\hline Utopenec & 54,3 & 31,3 & 74,3 & 10,9 & 34,2 & 19,9 & 39,6 & 3,5 \\
\hline Rybník & 63,9 & 37,1 & 77,1 & 7,5 & 10,1 & 2,9 & 15,1 & 2,9 \\
\hline Podviňák & 38,5 & 25,5 & 51,1 & 5,9 & 36,0 & 29,4 & 41,0 & 2,7 \\
\hline Chrástecký r. & 44,3 & 33,2 & 49,3 & 3,6 & 18,3 & 12,5 & 21,8 & 2,4 \\
\hline$J^{\prime} n^{*}$ & 61,9 & 47,2 & 71,2 & 5,1 & 37,0 & 21,6 & 47,3 & 5,9 \\
\hline Vyžlovský r. & 63,8 & 36,6 & 76,4 & 7,8 & 46,4 & 32,8 & 59,2 & 6,3 \\
\hline Švýcar & 49,1 & 34,8 & 62,7 & 5,7 & 31,6 & 15,6 & 41,1 & 5,0 \\
\hline Pařez & 45,0 & 22,1 & 60,0 & 8,4 & 28,4 & 21,0 & 33,5 & 2,5 \\
\hline Louňovický r. & 41,4 & 25,1 & 59,1 & 8,1 & 34,0 & 21,0 & 43,9 & 4,9 \\
\hline Požár & 53,6 & 20,8 & 73,0 & 9,1 & 36,8 & 23,1 & 47,3 & 5,3 \\
\hline Jevanský r. & 46,3 & 20,7 & 56,7 & 7,6 & 40,0 & 32,7 & 47,0 & 2,7 \\
\hline Nohavička & 40,7 & 24,6 & 50,5 & 5,6 & 42,8 & 35,0 & 47,6 & 2,9 \\
\hline Propast & 57,6 & 36,0 & 72,8 & 7,3 & 46,3 & 31,0 & 54,4 & 5,6 \\
\hline Hruškov & 60,3 & 30,2 & 81,1 & 8,9 & 32,7 & 19,2 & 38,7 & 4,0 \\
\hline
\end{tabular}

*uvedené hodnoty pro rybník Jan odpovídaji stavu préd rekonstrukcí (v současné době již tvar hráze odpovídá aktuálním normám) 
Výzkumný projekt NAKI II DG16P02M036 „Údržba, opravy a monitoring hrází historických rybníkủ jako našeho kulturního dědictví" je mimo jiné zaměřen na výzkum hrází historických rybníků. Tvar těchto hrází je významný jak s ohledem na stabilitu, tak s ohledem na průsaky těmito zemními tělesy. Výzkum tvaru hrází je proto jedním z hlavních úkolů řešených v rámci uvedeného projektu. Tvar je posuzován na základě různých datových podkladů v celkem čtyrech oblastech [9]. V průběhu výzkumných prací bylo zjištěno, že k danému účelu jsou nejvhodnějším podkladem podrobná výškopisná data vycházející z leteckého laserového skenování doplněná prípadně o data založená na vyhodnocení leteckých snímků pořizených prostřednictvím bezpilotních prostředků (UAV - Unmanned Aerial Vehicle) a vyhodnocených fotogrammetrickými metodami. Tento článek se zaměřuje na prezentaci dvou aspektů takto vedeného výzkumu. Předně jsou prezentovány výsledky posouzení sklonů svahů rybničních hrází v oblasti Kostelecka a Kouřimska. Pro toto posouzeni byla využita výškopisná data Digitálního modelu 5. generace pořizená od Českého úřadu zeměměřického a katastrálního. Na základě těchto výsledků pak byla zvolena hráz Podbečvárského rybníka, pro niž bylo provedeno posouzeni stability s využitím modelu Slope Stability Analysis Program - SSAP2010 [10].

\section{HODNOCENÍ TVARU HRÁZÍ}

Tvar hrází rybníků v zájmové oblasti byl posuzován s využitím nástrojů a metod GIS v prostředí ArcGIS. Zájmová oblast je definována jako území zahrnující povodí Jevanského potoka, Nučického potoka, Bylanky a částí povodí Šembery a Výrovky. Celková rozloha území činí 533,3km² a nachází se v ní celkem 31 rybníků s rozlohou nad 1 ha. Poloha těchto rybníků je patrná z mapy na obr. 1. Hráze menších rybníků (s rozlohou menší než 1 ha) nebyly posuzovány především z toho důvodu, že u menších rybníkủ by mohlo dojít ke značnému zkreslení výsledků z důvodu př́liš malého plošného rozsahu jejich svahů. Vedlejším důvodem pak byla skutečnost, že u menších rybníků jsou rizika vyplývající z případné poruchy hráze obecně menší.

\section{POSTUP HODNOCENÍ TVARU HRÁZE}

Podkladem pro hodnocení sklonů svahů hrází rybníků byla podrobná výškopisná data vycházející z leteckého laserového skenování povrchu. Konkrétně byl použit Digitální model reliéfu 5. generace (DMR5G) pořizený od Českého úřadu zeměměřického a katastrálního (ČúZK). Data jsou poskytována ve formě mračna bodů se souřadnicemi XYZ s průměrnou hustotou cca 1 bod na čtvereční metr. Výšková přesnost dat se pohybuje kolem 0,18 m v otevřeném terénu a 0,3 m v lesních porostech [11]. Předchozí výzkumy prokázaly, že takováto přesnost je postačující k popisu tvaru hrází [12]. Surová data poskytnutá ve formě ASCII souboru obsahujícím XYZ souřadnice byla nejprve konvertována do formátu ESRI SHAPEFILE a následně použita k vytvoření rastrové výškopisné vrstvy $\mathrm{s}$ rozlišením $0,5 \mathrm{~m}$. Z této vrstvy byla následně odvozena vrstva sklonů vyjádřených $v$ procentech.

Indikativní hodnoty sklonů návodního a vzdušního líce jednotlivých hrází byly stanovovány jako průměrné hodnoty $v$ rámci ručně vykreslených plošek s využitím zonální statistiky. Plošky byly vykreslovány tak, aby splňovaly následující požadavky:

- potřebu zahrnutí částí hrází s největšími sklony,

- dostatečnou velikost s cílem zajištění reprezentativnosti,

- vyloučení míst v okolí zdí, schodů a podobných konstrukcí, aby nedošlo ke zkreslení výsledků v důsledku zahrnutí napríklad svislých prvků.
Data DMR5G zahrnují pouze terén mimo vodní hladinu, z čehož vyplývá, že je nelze využít k popisu částí hrází, které se nachází pod hladinou. Z toho důvodu byly do posuzování zahrnuty pouze části návodních líců nacházející se nad hladinou, nebot doplňková výškopisná data vycházející ze snímkování při vypuštěném stavu byla dostupná pouze pro velmi omezený počet hrází a jejich zahrnutí by bylo na škodu konzistentnosti výsledků.

Indikativní hodnoty sklonů byly tedy uvažovány jako prostorové průměry sklonů stanovené $v$ rámci vykreslených plošek. K tomu byly doplňkově stanoveny i další popisné statistiky jako minimum, maximum a směrodatná odchylka.

\section{VÝSLEDNÉ HODNOTY SKLONU゚}

Výsledné hodnoty sklonů svahů jednotlivých posuzovaných hrází byly následně porovnány s nejprudšími hodnotami doporučenými pro homogenní hráze v normě ČSN 75 2410. Ty činí 1: 3 (33\%) pro návodní líc a $1: 2$ (50 \%) pro vzdušní líc. Konkrétně jsou tyto sklony doporučovány jako nejprudší pro hlinitý štěrk (GM) a hlinitý písek (SM), pro ostatní zeminy vhodné pro stavbu homogenních hrází jsou doporučovány u návodního líce mírnější sklony, u vzdušního líce sklony stejné či mírnější. Výsledné hodnoty sklonů pro posuzované hráze jsou uvedeny $v$ tabulce 1 .

Výsledné indikativní hodnoty sklonů nelze brát jako absolutní obecné hodnoty sklonů jednotlivých hrází, protože jsou založeny na posouzení vybraných částí. Je však možno je použít k identifikaci hrází s relativně strmými sklony. Ty je pak možno dále podrobněji analyzovat s ohledem na stabilitu. Z posuzovaných 30 rybníků mají pouze u 11 z nich hráze sklony mírnější na obou svazích, než jak doporučuje aktuálně platná norma. Na druhou stranu má celkem 8 rybníků hráze se sklony strmějšími oproti normativním hodnotám na obou svazích. V těchto osmi je zahrnuta i hráz rybníka Jan, který má v současnosti po rekonstrukci sklony mírnější. Celkově ovšem nejsou sklony svahů tak strmé, jak by odpovídalo doporučením popisovaným Dubraviem (1 : 1). V prípadě vzdušního líce dosahují nejvyšších hodnot sklonu hráze rybníků Rybník (63,9\%), Vyžlovský (63,8 \%), Hruškov (60,3%) a Podbečvárský (59,8 \%), v prípadě návodního líce hráze rybníků Vyžlovský (46,4%), Propast (46,3\%) a Nohavička (42,8 \%). Nejmírnější sklon vzdušního líce byl zjištěn u rybníka Hořejší (28,5 \%), návodního líce pak u rybníka Stojespal (8,8 \%).

\section{HODNOCENÍ STABILITY}

Z hodnocení hrází posuzovaných rybníků vyplývá, že nejstrmější sklony svahů vykazuje Vyžlovský rybník. Pro ten však nebyla k dispozici data potřebná k popisu tvaru celé hráze, jelikož nebylo možné provést snímkování hráze při vypuštěném stavu a provést vyhodnocení výškopisu podvodní části návodního svahu. Z toho důvodu byl pro posouzení stability hráze zvolen Podbečvárký rybník, který vykazoval velmi strmý sklon vzdušního líce a pro který tato data byla k dispozici, jelikož bylo možné jej nasnímkovat během výlovu. Rybník se nachází na toku Bečvárky v blízkosti obce Zásmuky (okr. Kolín). Rybník je zaznamenán již na mapách 1. vojenského mapování z druhé poloviny 18. století a je patrný i na Müllerově mapě Čech z roku 1720. Pro potřeby posouzení stability bylo nutné kromě tvaru hráze stanovit též parametry průsaku a parametry zeminy, z niž je hráz složena.

\section{TVAR HRÁZE}

Podrobně byl tvar hráze analyzován na základě detailního modelu terénu zpracovaného pomocí fotogrammetrických metod ze snímků pořízených s využitím UAV. Pořizené snímky byly zpracovány v prostředí Agisoft PhostoScan. Takto vytvořený 


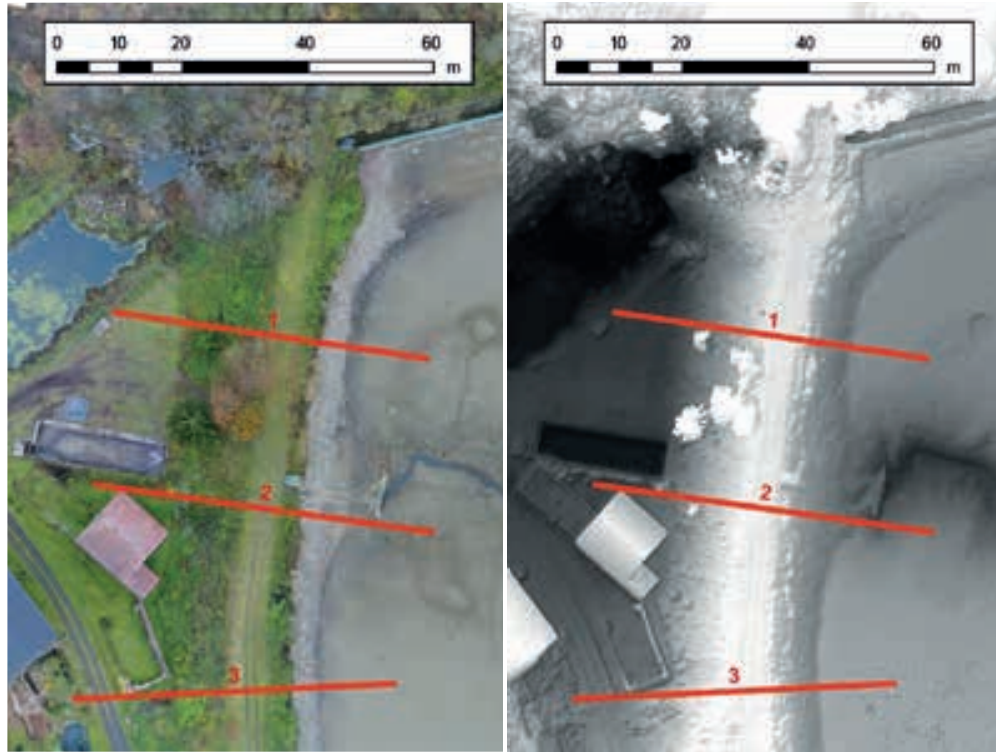

Obr. 2. Profily hrází Podbečvárského rybníka znázorněné na ortofotomapě (vlevo) a stínovaném reliéfu (vpravo)

Fig. 2. Cross-sections of Podbečvárský fishpond dam displayed over ortophoto (left) and hillshaded terrain (right)

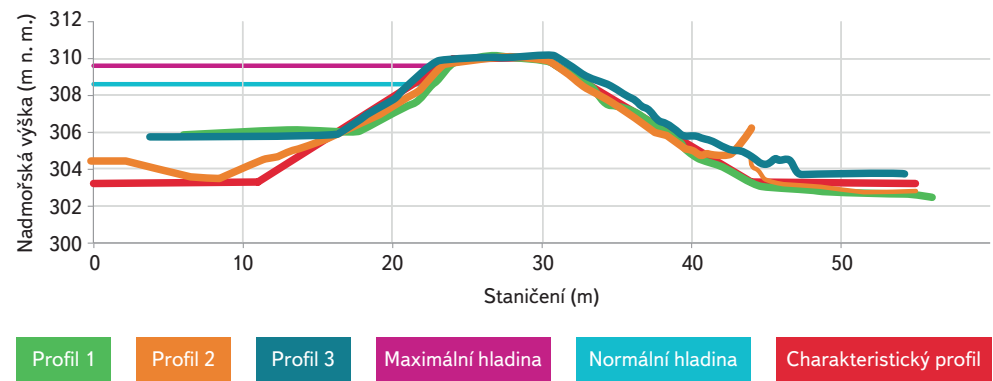

Obr. 3. Profily hrází Podbečvárského rybníka a charakteristický profil vytvoření na jejich základě

Fig. 3. Cross-sections of Podbečvárský fishpond dam and characteristic profile derived from them

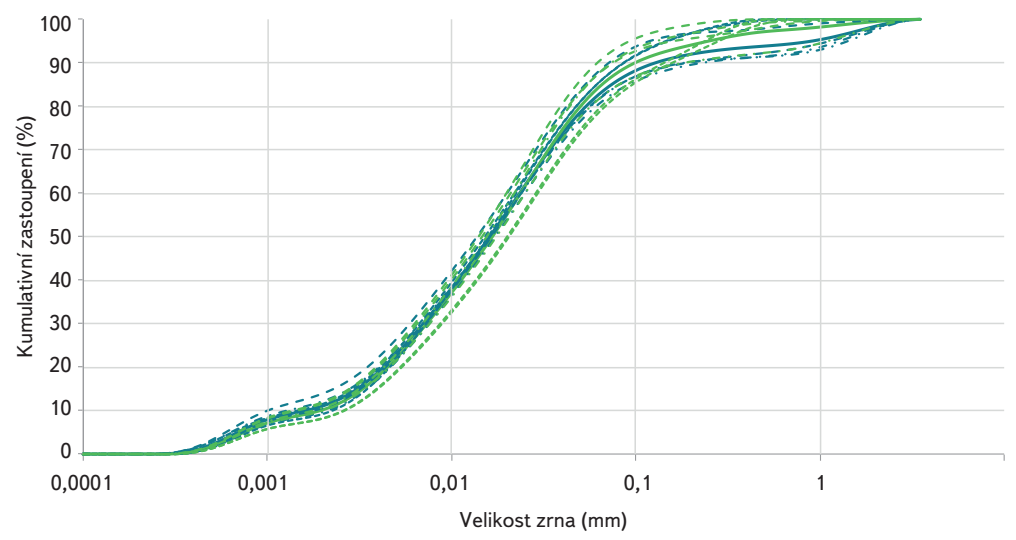

\section{SMP1}

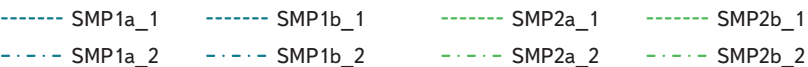

- . - SMP1a_3 - . - SMP1b_3 - - - SMP2a_3 - - - SMP2b_3

Obr. 4. Čáry zrnitosti zeminy hráze Podbečvárského rybníka

Fig. 4. Particle size distribution of the dam of Podbečvárský fishpond
Tabulka 2. Zastoupení zrnitostních frakcí v zemině hráze Podbečvárského rybníka Table 2. Grain size fractions of Podbečvárský fishpond dam earth material

\begin{tabular}{llll} 
Frakce & $\begin{array}{l}\text { Zastoupení } \\
\min .[\%]\end{array}$ & $\begin{array}{l}\text { Zastoupení } \\
\max .[\%]\end{array}$ & $\begin{array}{l}\text { Zastoupení } \\
\text { průměr [\%] }\end{array}$ \\
\hline jíl & 8 & 14 & 11 \\
\hline prach & 69 & 78 & 73 \\
\hline písek & 10 & 22 & 15 \\
\hline štěrk & 0 & 3 & 1
\end{tabular}

podrobný digitální model byl následně použit k popisu geometrie hráze. Modelem byly vedeny tři profily, na jejichž základě byl vykreslen charakteristický profil, který byl vstupem pro hodnocení stability. Použité profily jsou znázorněny na obr. 2.

Jednotlivé zpracované profily byly následně použity za účelem vytvoření charakteristického profilu hráze. Ten byl připraven tak, aby reflektoval tvar zachycený těmito profily. Jednotlivé profily včetně charakteristického profilu jsou znázorněny na obr. 3.

\section{MATERIÁL HRÁZE}

Zemina, z níž je hráz konstruována, byla analyzována na základě dvou porušených vzorků odebraných z jejího tělesa. Tyto vzorky byly následně laboratorně analyzovány s cílem zjistit zrnitostní složení zeminy. K tomu byl využit laserový analyzátor Mastersizer 3000, který umožňuje zrnitostně analyzovat materiály do velikosti zrna 3 mm. Každý vzorek byl rozdělen na dva dílčí. Každý dílčí vzorek byl analyzován jak bez ultrazvukového rozrušení agregátů, tak s jeho využitím. Všechny takto získané čáry zrnitosti vykazují velmi podobný průběh, jak je patrné z jejich znázornění na obr. 4.

Ze získaných čar zrnitostí bylo následně stanoveno procentuální zastoupení jednotlivých frakcí: jílovité ( $<<0,002 \mathrm{~mm})$, prachové $(0,002<\mathrm{d}<0,063 \mathrm{~mm})$, písčité $(0,063<d<2 \mathrm{~mm})$ a štěrkové $(\mathrm{d}>2 \mathrm{~mm})$. Největší zastoupení měla jemnozrnná frakce - jíl a prach (84\%), zatímco hrubozrnná byla zastoupena mnohem menší měrou (16\%). Podrobné zastoupení jednotlivých zrnitostních frakcí je uvedeno v tabulce 2. Na základě zastoupení jednotlivých frakcí a stanovených hodnot plasticity (vlhkost na mezi tekutosti $42 \%$, index plasticity $11 \%$ ) byla zemina zatříděna jako hlína se střední plasticitou.

\section{STANOVENÍ PRŮSAKU}

Prítomnost vody v tělese hráze je jedním z faktorů významně ovlivňujících její stabilitu. Z toho důvodu bylo nutno stanovit průběh hladiny vody v tělese hráze pro jednotlivé uvažované zatěžovací stavy. K tomuto účelu byl použit postup výpočtu průsaku pro homogenní hráze podle Kudina [13]. Tvar průsakové křivky je dán rovnicí paraboly (viz rovnice 1), která má počátek v místě patního drénu či paty vzdušního líce a teoretickou délku $L(m)$, přičemž průběh je závislý na hydraulické výšce $H(m)$. U uvedeného vztahu je počátek souřadné soustavy umístěn $v$ patním drénu, osa $x(m)$ směřuje horizontálně proti směru proudění vody a osa y $(m)$ svisle vzhůru:

$$
y^{2}=x \cdot \frac{H^{2}}{L}
$$




\section{HODNOCENÍ STABILITY}

Pro posouzení stability zvolené hráze byl použit model Slope Stability Analysis Program SSAP2010. Tento nástroj používá k hodnocení stability metodu Morgenstern-Price pro výpočet stupně stability [14]. Software umožňuje hodnocení stability ve 2D a zahrnuje i modul pro generování možných smykových ploch založený na metodě Monte-Carlo. Model byl v minulosti ověřen a použit pro různé aplikace související s posuzováním stability svahů [15-17].

Pro potřeby posouzení stability svahů hráze vybraného rybníka bylo toto zemní těleso uvažováno jako homogenní s geometrií popsanou výše. Fyzikální parametry zeminy použité pro hodnocení byly odhadnuty na základě orientačních hodnot uvedených normou ČSN 75 2410. Posouzení bylo provedeno ve třech variantách od nejpříznivější (Var1), přes střední (Var2) po nejméně příznivou (Var3) s ohledem na stabilitu, přičemž v rámci jednotlivých variant byly uvažovány různé hodnoty pro soudržnost a úhel vnitřního tření. Použité hodnoty jsou uvedeny $v$ tabulce 3.

Tabulka 3. Hodnoty smykových parametrů zeminy použité pro hodnoceni stability hráze Podbečvárského rybníka

Table 3. Geotechnical parameters of earth material used for stability assessment of Podbečvárský fishpond dam

\begin{tabular}{llll} 
Parametr & Var1 & Var2 & Var3 \\
\hline Soudržnost zeminy při efektivním napětí $c_{\text {ef }}(\mathrm{kPa})$ & 6 & 5 & 4 \\
\hline Úhel vnitřního tření při efektivním napětí $\left.\varphi_{\text {ef }}{ }^{\circ}\right)$ & 31 & 24 & 17 \\
\hline Specifická tíha nasycené zeminy $\gamma_{\text {sat }}\left(\mathrm{kN} \cdot \mathrm{m}^{-3}\right)$ & & 26 & \\
\hline Specifická tíha vysušené zeminy $\gamma_{\text {dry }}\left(\mathrm{kN} \cdot \mathrm{m}^{-3}\right)$ & 21 &
\end{tabular}

\section{VÝSLEDKY HODNOCENÍ STABILITY}

Výsledky hodnocení stability hráze Podbečvárského rybníka přinášejí několik poznatků. Předně jsou některé vypočtené hodnoty stupně stability nižší, než požaduje norma ČSN 75 2310. Konkrétně dosáhla nejnižší vypočtená hodnota pro vzdušní líc 1,34 pro variantu 2 (střední hodnoty smykových parametrů), přičemž norma požaduje pro ustálený stav hodnotu 1,50 pro zatěžovací stav po dokončení nádrže pro všechny varianty hladiny (nádrž plná, nádrž částečně naplněná, nádrž prázdná) s výjimkou prípadu, kdy jsou pórové tlaky měřeny, což není prípad posuzované hráze [18]. Pro variantu 3 (nepříznivé hodnoty smykových parametrů), klesly dokonce hodnoty stupně stability pod 1 (konkrétně 0,98),

Tabulka 4. Minimální hodnoty stupně stability pro jednotlivé uvažované varianty a úrovně hladin

Table 4. Minimum safety factor values for considered variants and water levels

\begin{tabular}{lllll} 
& & Var1 & Var2 & Var3 \\
\hline \multirow{2}{*}{ Návodní líc } & plná nádrž & 4,96 & 3,62 & 2,49 \\
\cline { 2 - 5 } & normální stav & 3,23 & 2,39 & 1,73 \\
\cline { 2 - 5 } & prázdná nádrž & & 2,12 & \\
\hline \multirow{2}{*}{ Vzdušní líc } & plná nádrž & 1,71 & 1,35 & 0,98 \\
\cline { 2 - 5 } & normální stav & 1,69 & 1,34 & 0,98 \\
\cline { 2 - 5 } & prázdná nádrž & & 2,08 &
\end{tabular}
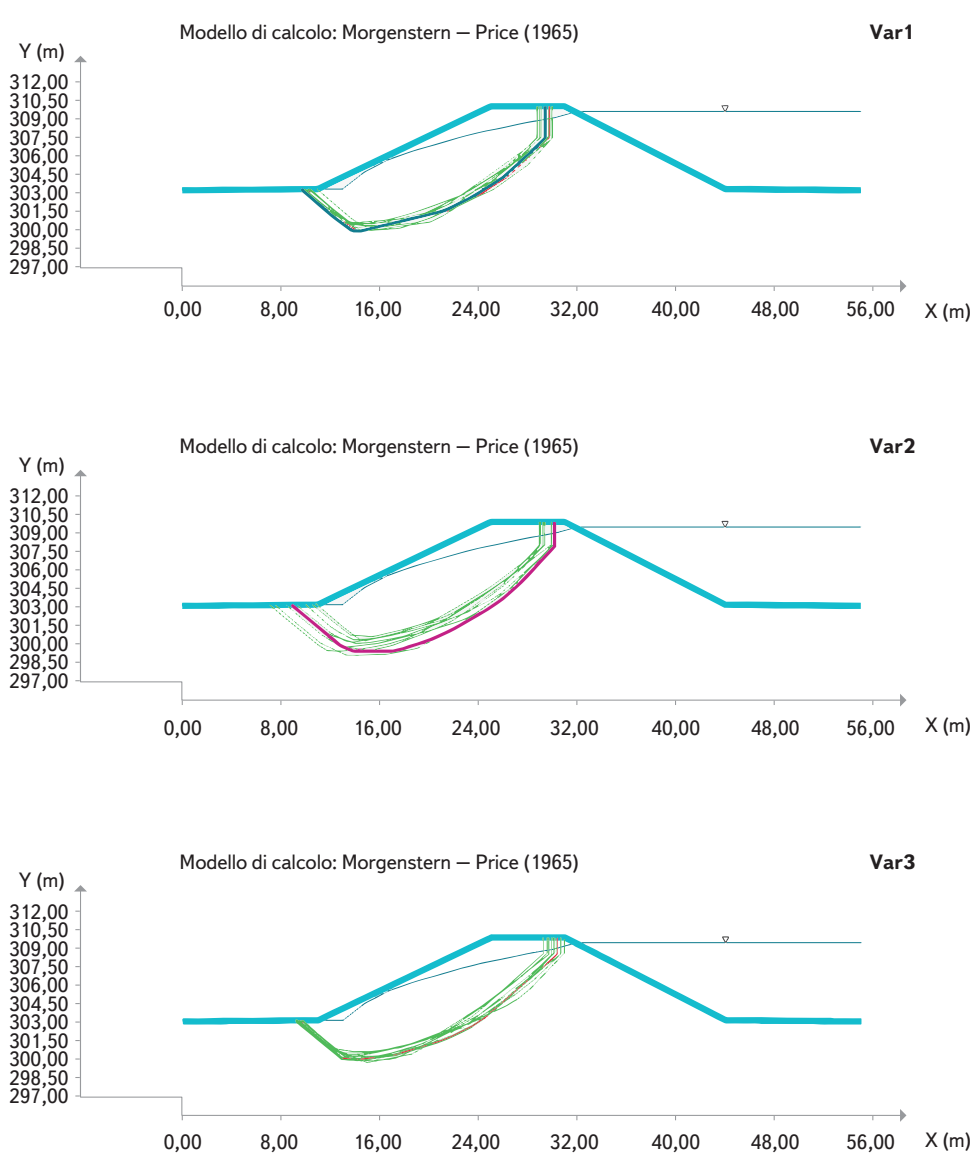

Obr. 5. Průběh deseti nejkritičtějších smykových ploch na vzdušním líci pro maximální úroveň hladiny vody v nádrži

Fig. 5. Ten most critical sliding surfaces on downstream face for maximum water level in reservoir

což představuje nestabilní svah. Průběh deseti nejkritičtějších smykových ploch pro vzdušní líc pro jednotlivé varianty úrovně hladiny vody v nádrži je znázorněn na obr. 5-7, hodnoty stupně stability pro všechny uvažované kombinace jsou uvedeny v tabulce 4. Výsledky ovšem nelze chápat tak, že je hráz ohrožena sesuvem, což ostatně koresponduje se skutečností, že v průběhu posledních staletí nedošlo k jejímu porušení, její bezpečnost však je pravděpodobně nižší, než požaduje současná norma. K detailnímu posouzení stability by ovšem bylo nutné provést stanovení fyzikálních vlastností zeminy na základě geotechnických zkoušek.

Druhým zjištěním je fakt, že stupeň stability a průběh nejkritičtějších smykových ploch na vzdušním svahu se príliš nemění v porovnání obou uvažovaných úrovní hladiny. Dưvodem je patrně skutečnost, že průběh použité průsakové křivky není pro oba stavy v rámci kritické zóny prríliš odlišný. Pro prázdnou nádrž činí minimální hodnota stupně stability pro vzdušní líc 2,08, což znamená, že má dostatečnou stabilitu i s ohledem na požadavky normy.

$\checkmark$ př́padě návodního svahu tělesa hráze se pohybují hodnoty stupně stability ve všech uvažovaných prípadech nad normou požadovanou hodnotou 1,5. Mimo to je návodní líc hráze částečně opevněn kamenem (obr. 8), což nebylo v posuzování stability zohledněno. Při zahrnutí této skutečnosti by byly výsledné hodnoty stupně stability ještě vyšší. 

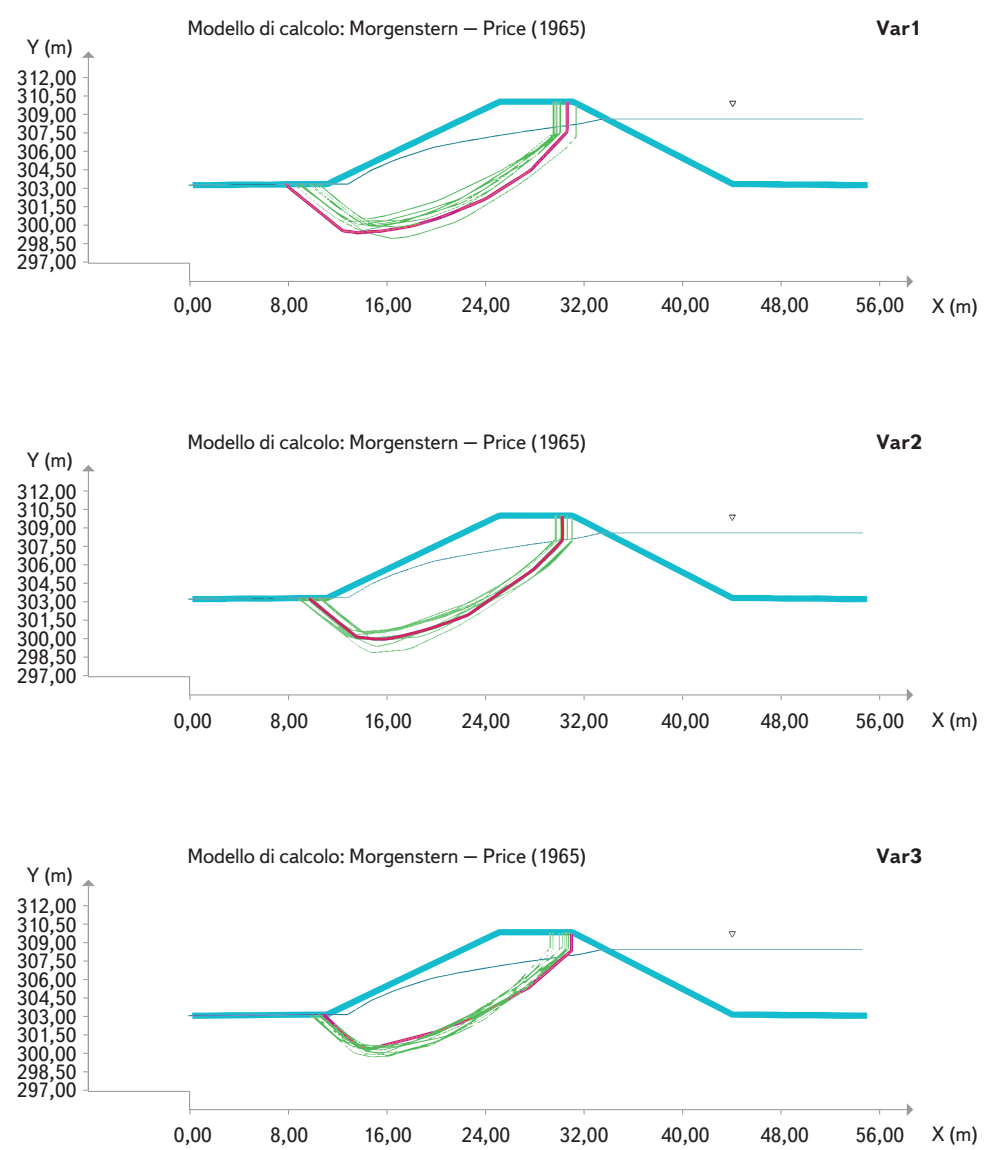

Obr. 6. Průběh deseti nejkritičtějších smykových ploch na vzdušním líci pro normální úroveň hladiny vody $v$ nádrži

Fig. 6. Ten most critical sliding surfaces on downstream face for normal water level in reservoir

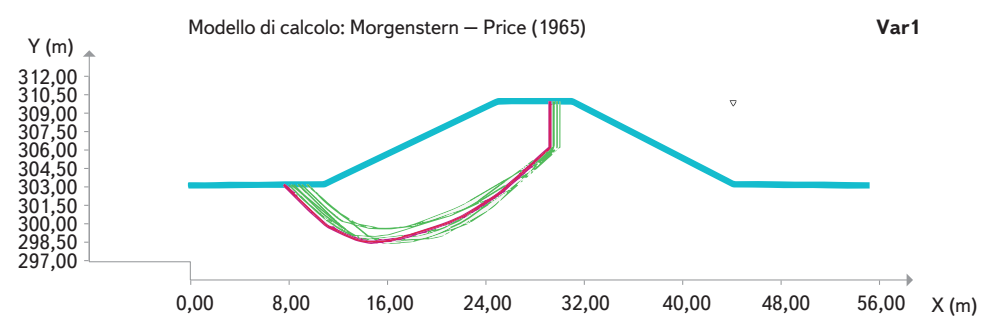

Obr. 7. Průběh deseti nejkritičtějších smykových ploch na vzdušním líci pro nádrž bez vody (pro prázdnou nádrž byly posuzovány pouze totální hodnoty parametrư v jedné variantě)

Fig. 7. Ten most critical sliding surfaces on downstream face for empty reservoir (in this case, only total parameters were considered in one variant)

\section{ZÁVĚR}

Potřebu posuzování tvaru hrází historických rybníků Ize na základě výsledků provedených analýz prezentovaných $\vee$ tomto článku považovat za oprávněnou. Předně bylo potvrzeno, že historické rybníky mají často hráze se sklony prudšími, než doporučují současné normy. To může být příčinou nižší stability a zvýšeného rizika poruch či havárií vedoucích v nejhorších případech až ke vzniku zvláštních povodní. Na příkladu hráze Podbečvárského rybníka bylo ukázáno, že stabilita hrází historických rybníků skutečně může být nižší, než je v současnosti požadováno. V tomto případě se jedná o hráz, která je velmi

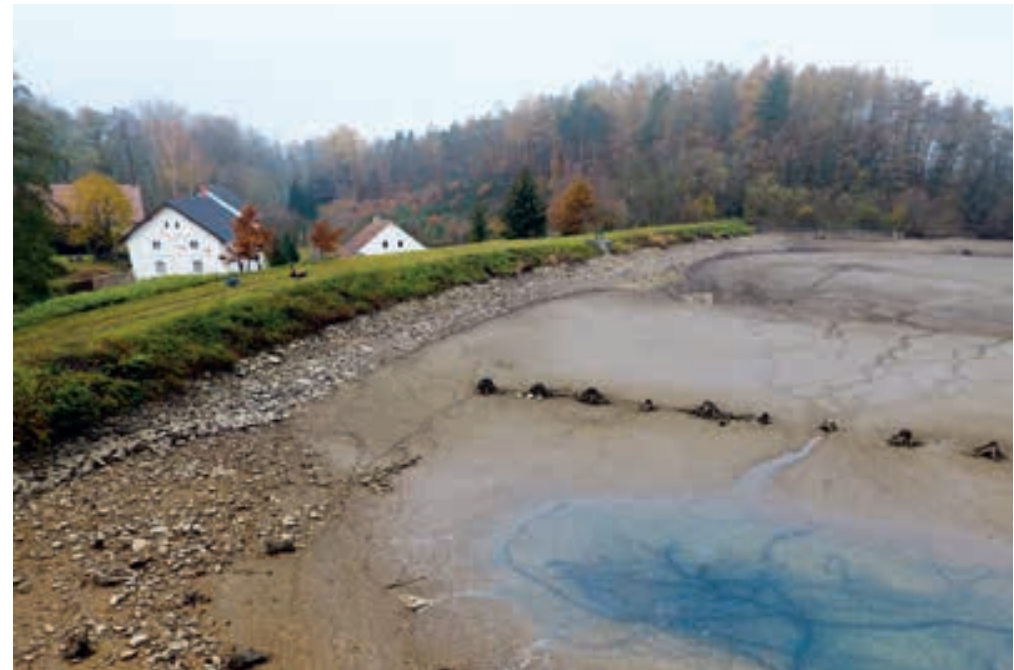

Obr. 8. Návodní líc hráze Podbečvárského rybníka

Fig. 8. Upstream face of the dam of Podbečvárský fishpond

strmá v rámci obou svahů - návodního i vzdušního. Výsledky posouzení stability představují v nejhorším př́padě hodnotu stupně stability 0,98, což by představovalo značné riziko. Jedná se však o hodnotu stupně stability odpovídající variantě pro velmi nepríznivé hodnoty parametrů zeminy, které představují extrémní prípad. Ovšem i pro variantu středních hodnot parametrů je stupeň stability nižší, než je požadováno normou pro sypané hráze. To přináší nežádoucí zvýšení rizik plynoucích z existence této stavby. Hráz Podbečvárského rybníka byla použita pouze jako príklad, ale i tak Ize na základě dosažených výsledků konstatovat potřebu detailnějšího monitoringu hrází historických rybníků. Představený postup, zahrnující jak obecné hodnocení tvaru hrází, tak detailní analýzu těch vybraných, může být prospěšný v případě posuzování rybníků v širších oblastech a identifikaci potenciálních rizik.

\section{Poděkování}

Výzkum prezentovaný v tomto článku byl realizován v rámci výzkumného projektu NAKI II DG16P02M036 „Údržba, opravy a monitoring hrází historických rybníkü jako našeho kulturního dědictvi" financovaného Ministerstvem kultury České republiky.

Článek je upravenou a rozšírenou verzí příspěvku publikovaného $v$ anglickém jazyce na konferenci 38 th IAHR World Congress, konané 1. až 6. zárí 2019 $\checkmark$ Panamě.

\section{Literatura}

[1] KUKLÍK, K. a HRBÁČEK, J. České a moravské rybníky. Praha: Pressfoto, 1984, 83 s.

[2] HRDINA, K. Kronika česká: K. vyd. připravil a úvodní statí spolu s doslovem a rejstř́kem doprovodil Karel Hrdina. Praha: Melantrich, Vol. 10, 1949.

[3] DUBRAVIUS, J. De piscinis ad Antonium Fuggerum. Praha: Nakladatelství Československé akademie věd, 1953, Vol. 1 .

[4] LIEBSCHER, P. a RENDEK, J. Rybniky České republiky. Praha: Academia, 2014, 584 s.

[5] ANDRESKA, J. Lesk a sláva českého rybářstvi. 1. vyd. Praha: NUGA, 1997, 166 s.

[6] MÍKA, A. a ŠTOCHL, S. Naše rybníky a přehradníjezera. Praha: Orbis, 1963, 256 s.

[7] ÚNMZ. ČSN 752410 Malé vodní nádrže. Praha: Úřad pro technickou normalizaci, metrologii a státní zkušebnictví. 2011.

[8] VANIČEK, I., VANIČEK, J., and PECIVAL, T. Risk evaluation of domino effect of dam failures on small river-basins. In: E3S Web of Conferences, EDP Sciences. 2016, Vol. 7, p. 07009. 
[9] DAVID, V. a DAVIDOVÁ, T. Analýza vybraných morfologických charakteristik pro rybniční sítě ve čtyřech oblastech. Vodohospodářské technicko-ekonomické informace, 2017, roč. 59, č. 1, s. 4-11. ISSN 0322-8916.

[10] BORSELLI, L. Advanced 2D slope stability analysis by LEM by SSAP software: a full freeware tool for teaching and scientific community. ICL landslide teaching tools, International Consortium on Landslies (ICL), 2013, 428 p.

[11] BRÁZDIL, K. Technická zpráva k digitálnímu modelu reliéfu 5. generace (DMR 5G). Pardubice, Český úřad zeměměřický a katastrální. 2012.

[12] DAVID, V., KRÁSA, J., KOUDELKA, P., and DAVIDOVÁ, T. Elevation data for morphometric analysis of historical ponds dams. Proceedings of the $17^{\text {h }}$ International Multidisciplinary Scientific GeoConference. Albena, Bulgaria, 2017, 17, p. 481-488,

[13] ŠÁLEK, J., MIKA, Z. a TRESOVÁ, A. Rybniky a účelovénádrže. Praha: SNTL, 1989, 267 s.

[14] MORGENSTERN, N.R., and PRICE, V.E. The analysis of the stability of general slip surfaces Geotechnique, 1965, 15 (1), p. 79-93.

[15] BORSELLI, L., CAPRA, L., SAROCCHI, D., and DE LA CRUZ-REYNA, S. Flank collapse scenarios at Volcán de Colima, Mexico: a relative instability analysis. Journal of Volcanology and Geotherma Research, 2011, 208 (1-2), p. 51-65.

[16] BRUNETTI, M.T., GUZZETTI, F., CARDINALI, M., FIORUCCI, F., SANTANGELO, M., MANCINELLI, P., KOMATSU, G., and BORSELLI, L. Analysis of a new geomorphological inventory of landslides in Valles Marineris, Mars. Earth and Planetary Science Letters, 2014, 405, p. 156-168.

[17] TORRI, D., BORSELLI, L., CALZOLARI, C., YAŇEZ, M.S., and SALVADOR SANCHIS, M.P. Soil erosion, land use, soil quality and soil functions: effects of erosion. In: Man and Soil at the Third Millennium Rubio, J. L., Morgan, R. P. C., Asins, S., Andreu, V. (eds.). Geoforma Ediciones: Logroňo, 2002, p. 131-148

[18] ÚNMZ. ČSN 752310 Sypané hráze. Praha: Úřad pro technickou normalizaci, metrologii a státn zkušebnictví. 2006

\section{Autoři}

Ing. Kateřina Černochová

凶katerina.cernochova@fsv.cvut.cz

Ing. Václav David, Ph.D.

凶vaclav.david@fsv.cvut.cz

České vysoké učení technické v Praze, Fakulta stavební

Príspěvek prošel lektorským řízením.

\section{THE DAMS OF HISTORICAL PONDS IN TERMS OF SHAPE AND STABILITY}

\section{CERNOCHOVA, K.; DAVID, V.}

Czech Technical University in Prague, Faculty of Civil Engineering

Keywords: fishpond - dam shape - dam stability - Kostelecko

The article presents the results of the evaluation of the fishpond dams shape in the region of Kostelec and Kouřim in the Central Bohemian Region. The shape of the dams was assessed on the basis of a detailed digital terrain model derived from the data of Digital Relief Model of $5^{\text {th }}$ Generation. The assessment was carried out for a total of 30 dams in the study area. The results of the analyses show that many fishpond dams have steep slopes with steepness higher than recommended for homogeneous dams by the current standard ČSN 752410. Stability assessment was then performed for the selected dam of the fishpond Podbečvárský using the SSAP model. The results of stability assessment show that the dam does not have the stability factor required by the standard ČSN 75 2410, although this does not mean that it would be acutely endangered. The presented procedure represents a possible way to approach the safety assessment of the dams of small water reservoirs in larger areas in order to identify the potential hazards associated with reduced stability of these earth bodies. 